\title{
Peculiarities of assertive behavior development of future lecturers under the Master's Degree Program conditions
}

\author{
O. V. Horodnychyi
}

\author{
Alfred Nobel University \\ Corresponding author. E-mail: gorodnichiy@gmail.com
}

Paper received 02.09.20; Accepted for publication 24.09.20.

\section{https://doi.org/10.31174/SEND-PP2020-236VIII94-20}

\begin{abstract}
Annotation. The article analyzes the specifics of the formation of assertive behavior of the personality in the process of professional training, in particular, identifies the peculiarities of assertive behavior development of future lecturers under the Master's Degree Program conditions. The conditions of formation of assertive behavior of future specialists in the higher education institution environment are considered. It is emphasized that the educational process as a student-lecturer interaction should be built on the principle of assertiveness, which is based on mutual respect, friendly perseverance, correct management of students' learning.
\end{abstract}

Keywords: assertiveness, assertive behavior, future lecturers, Master's Degree Program.

Introduction. In today's difficult conditions, social factors play a significant role in maintaining the psychological balance of the specialists' personality in various fields. In this context, the development of assertive behavior professional quality, which is manifested in confident decisions making as a reaction to socio-psychological changes, as well as in psychological balance and ethical attitude to other participants in the educational environment, is important, especially for lecturers of higher education institutions. The need to develop assertiveness and the formation of assertive behavior of future lecturers of higher education institutions is caused, on the one hand, by the requirements of the current education system in Ukraine, and on the other - by the reorientation of modern youth to active learning, which requires lecturers to be constantly prepared for unpredictable professional situations and the ability to adhere to the chosen course of action even under the influence of stressors. In this regard, it is important to consider assertive behavior as one of the important personality traits of future lecturers when studying in a higher education institution, where learning is the main activity for students under the Master's Degree Program conditions.

A brief overview of relevant publications. The works of H. Ball, E. Holovakha, O. Donchenko, M. Savchyn, V. Tatenko, T. Tytarenko, O. Khokhlova and others are devoted to the study of the peculiarities of assertive behavior of personality. The pedagogical aspect of this problem was considered by I. Bekh, S. Bishop, O. Merzliakova, V. Miliaieva, O. Petrunko, N. Pobirchenko, S. Udovytska and others.

Assertive behavior acquires exceptional significance in the professional dimension, as it is the leading means to achieve the mutual understanding and agreement in the team, allows to ensure successful professional development and a high level of psychological well-being of the specialist (O. Bondarchuk, V. Klymenko, T. Kudriavtseva, H. Lozhkin, Y. Povarenkov, L. Podoliak, N. Priazhnikov, V. Yurchenko, etc.). These qualities are extremely important in the work of a lecturer of higher education institution.

At the same time, researchers ignore the issues that determine the peculiarities of the manifestation of assertive behavior in the professional environment of the higher education institution, in particular, during educational and professional activities. It is the inadequacy of the devel- opment of this problem that leads to its more thorough study, so the objectives of the article is to analyze the peculiarities of assertive behavior development of future lecturers under the Master's Degree Program conditions.

Description of the main material. The assertive behavior in the educational process is understood as the optimal version of communication between lecturer and students, which leads to the formation of a responsible personality who can successfully solve psychological, educational, industrial problems [9, p. 119]. The assertiveness of the lecturer is the orientation of his or her actions to create conditions for the participant to conduct the independent actions with the initial responsibility for the choice and consequences of one's actions. Everything must be subordinated to an important goal: to teach the students to study independently, to live fully, to work in any conditions, to restructure their activities depending on the circumstances. The attitude to the personality is based on the recognition of his or her individuality; stimulation of maximum self-expression; opportunities for the personality to fully realize oneself [8].

In this context, the opinion of V. Semychenko on the specific role of creating a favorable atmosphere of the educational institution in the formation of worldview, ideals, moral principles and professional values of students is important [14]. Therefore, we can say that the issue of providing the necessary conditions for the assertive behavior development of future lecturers requires a comprehensive approach and involves the cooperation of students, master students, lecturers and the administration of educational institutions.

The educational process in higher education institutions includes the interaction of lecturers and students (master students), in the process of which the didactic goal is realized, as well as psychological and pedagogical influence (external conditions) through methods, techniques, technologies (correctional, developmental, educational), that contribute to the disclosure of individual traits of each student and master student, the upbringing of a high level of moral activity of the personality, respect for others, the development of critical thinking and resistance to manipulation through confident, socially active assertive behavior. Thus, another significant psychological condition for the development of assertive behavior is the educational institution environment, its psychological and pedagogical influences [3]. 
The formation of assertiveness as a personality trait of a future higher education institution lecturer primarily involves a person's awareness of how much his or her behavior is determined by his or her own inclinations and motivations, and how much by someone's imposed attitudes. It often turns out that the pedagogue is under the power of attitudes far from his or her true nature, and suffers from it. Lecturer is invited not only to take the leading role in the script of his or her own life, but also to rewrite the script and direct the entire production actually [6].

According to I. Kozych, the source of assertiveness of the future higher education institution lecturer should be a sense of professionalism, competence, i.e. when he or she knows how, by what means, methods, techniques it is possible to make positive changes in communication with students or colleagues, prevent conflict, relieve tension. An assertive lecturer has a right to: demand the attention and involvement of the audience; seek compliance with the rules of the discipline; insist on tasks execution. An assertive lecturer is not afraid to: be tough (sometimes); be soft (sometimes); joke and play (sometimes); face aggression, irritability, threats, indifference or excessive enthusiasm of students. The basis for all these techniques is mutual respect, friendly perseverance, polite demanding. A confident assertive lecturer clearly knows his or her goals, tasks, the plan of own activity, his or her own strengths, as well as the limitations [5].

The ability to experience deeper, existential feelings allows the formation of an assertive position, which is based on a conscious rejection of violent methods of influence and the predominant use of persuasion methods in relation to other people. Therefore, we can say that a student or master student has an understanding and awareness of oneself and others. In such situation a positive attitude towards oneself and other people leads to interpersonal interaction [7].

However, today we can state the contradiction between the need to form the skills of assertive behavior of future lecturers and the fact that currently in psychological and pedagogical science there is no single concept of organizing the future lecturers training on the basis of assertive approach. A convincing proof of this is the current system of future professionals training to form a new type of relationship in the process of professional development. According to E. Khokhlova, responsibility, compromise and willingness to cooperate should be the main components of such relations [17].

At the same time, L. Hrymak, P. Stepanov and S. Samygin consider this problem from a different angle. Thus, scientists claim that today the educational process is influenced by the defining characteristics of young students, in particular, audacity, competition in education, where everyone plays for oneself; lack of common interests, mutual support and assistance to each other. All this contradicts with the principles of education itself, the essence of which is based on the positions of cooperation. In addition, a number of young people who feel lonely, do not believe in themselves or others, increases. Such people seek to solve the problems that arise on their own, using existing methods and means. In this context, the development of assertive behavior of students and master students can also be a solution to the problem of growing hostility and overcoming destructive relationships in higher education institutions $[4 ; 13 ; 15]$.

According to M. Buianova, the main reason for the failure to form an effective motivational strategy of behavior for students and master students in the educational process is to focus exclusively on external, objective criteria of success (image, financial status, career, approval of others and more). It is because of such external criteria of success that the most probable is the appearance of fear of failure, failure to achieve goals, and hence the development of a strategy to avoid failure [2].

O. Khokhlova emphasizes the need for such psychological and pedagogical work on the development of assertive behavior, which should be aimed at understanding of oneself and one's capabilities, increasing confidence in one's own personality, self-confidence, altruistic skills [17, p. 15-16]. To this end, it is necessary to develop such personal and behavioral traits that lie in the structure of an assertive personality, i.e. positive openness, free expression of feelings and emotions during behavior, energy, purposefulness, courage to defend one's beliefs, self-confidence as an indicator of value attitude to oneself and other people, initiative in contacts as a manifestation of activity in the direction of development and cognition.

Well-known scientist S. Bishop suggests the training in the development of confidence (assertiveness) as a way to correct behavior, build self-confidence, increase selfesteem and promote sincere and effective communication [1, p. 9-10].

Scientist J. Ramirez in his work argued that the formation of assertive behavior in education is marked by the spread of positive influence on the whole group, especially during the further interaction [19].

N. Razhyna considers the important condition for the development of assertive behavior of students and master students in the educational process, which is the personal self-confidence increase, which contributes to personal maturity and is reflected in such strategies of interaction as compromise and cooperation [12, p. 109]. The development of skills of critical thinking and analysis of the situation, the implementation of constructive interaction, respect to oneself and others, understanding of one's own purpose and what the communication partner seeks, adequate self-esteem are important here [10].

The psychological support of students with assertive behavior and the formation of motivation for the assertive behavior development play an important role here. N. Khamska offers "subject-subject interaction of the educator and pupils, dialogization of communication, understanding, recognition and acceptance of another individual as a unique personality; formation of the core of personal dignity of everyone; use of innovative forms of work", which provides the achievement of such important conditions in extracurricular activities, as value attitude to others and to oneself, self-cognition and reflection, stable values of life, the ability to behave politely and share one's own experience with others, etc. [16, p. 183].

Students interact in the process of interpersonal contacts within the group, communicate with each other actively and gain individual experience. It is important that the expression of the individuality of the personality in the system of social relations reflects his or her social 
position, which is based on moral guidelines and their active reflection in appropriate behavior and actions. Developmental environment as an external influence on behavior can be created for students and master students through socio-psychological trainings, elective courses, classes with elements of training, individual developmental classes. They must be active in the formation of the necessary knowledge and skills for the implementation of assertive behavior, meet the age needs of young people and the requirements of today, ensure the development of awareness of one's own behavior, its effectiveness, create an atmosphere of freedom in communication and interpersonal interaction, to have a feedback [18].

Thus, the above allows us to conclude that under the Master's Degree Program conditions there are quite significant changes in the professional development of students who will become future lecturers of higher education institution. The peculiarities of this process are due to the specifics of professional activity in higher education institution and the requirements that society puts forward for this type of training. All this causes the necessity of analysis of the current system of specialists' training for higher education institutions and the creation of conditions that will promote the formation of their assertive behavior in the context of the process of professional development.

The system of assertiveness development can include both purposeful activities in educational classes in any subject, and classes in specially formed training groups. As practice shows, in the classroom the formation of students' personal traits necessary for assertive behavior can be held on the basis of the principles of development of students' cognitive activity, and it depends on the skill of the lecturer. According to these principles, the lecturer has a psychological impact on students with an interesting short story, demonstration of experiments, unexpected questions, unusual behavior to capture their attention and arouse their interest. Then the lecturer turns the interest that arises into curiosity, a problem situation building, focusing on the contradictions in the proposed situation or in the observed phenomena. Students have a cognitive need and begin the active mental activity aimed at solving the problem, which arose [11].

The lecturer encourages any options for the problem solving offered by students, which contributes to the development of confidence, independence, initiative. In the process of discussing the problem solutions under the guidance of a competent lecturer, students learn to respect the opinions of others, to control themselves, their statements, emotions and behavior. After discussing possible solutions of the problem, their advantages and disadvantages, a generalized reasoned conclusion is made. The gradual complication of the educational problems offered by students while maintaining their interest in the process of solving problem situations contributes to the development of their perseverance, determination, ability to bring the case to an end [11].

Conclusions. Thus, the systematic, consistent inclusion of students into the process of new knowledge and skills acquiring will promote the development of all personal qualities that make up the structure of assertiveness. Therefore, the educational process as a interaction between student and lecturer should be built on the principle of assertiveness, which is based on mutual respect, friendly perseverance, correct management of student learning.

\section{ЛІТЕРАТУРА}

1. Бишоп С. Тренинг ассертивности. Санкт-Петербург: Питер, 2001. 208 с.

2. Буянова М. В. Личностные и ситуативне факторы мотивации достижения. Ананьевские чтения-2004. Материалы научно-практической конференции. СанктПетербург: Изд-во С.-Петербургского университета, 2004. C. 243-244.

3. Глубока І. О. Особливості створення психологічних умов розвитку асертивної поведінки учнів професійнотехнічних навчальних закладів. Молодий вчений. 2016. № 5. C. 548-552.

4. Гримак Л. П. Общение с собой. Начала психологии активности. Москва: Издательство политической литературы, 1991.320 с.

5. Козич I. В. Асертивна поведінка як новоутворення процесу формування конфліктологічної компетентності майбутнього педагога вищої школи. Вісник Запорізького національного університету. Педагогічні науки. 2014. № 1. C. $135-143$.

6. Коробкова Т. А. Ассертивность как вид педагогической коммуникации. Сборник научных трудов конференции «Высокие технологии в педагогическом процессе». Нижний Новгород: Изд. ВИПИ, 2000. С. 138-139.

7. Марчук Л. М. Асертивна позиція студента як змістовна характеристика екзистенції. Актуальні проблеми психології: зб. наук. пр. Ін-ту психології імені Г.С. Костюка Т. ХІ: Соціальна психологія. Київ: ДП «Інформаційно-аналітичне агентство», 2013. Вип. 6. С. 95-102.

8. Марчук Л. М., Соболь Н. M. Психолого-педагогічні аспекти формування асертивної поведінки студентів

\section{вищої} df (дата звернення: 06.04.2018)

9. Марчук Л. М. Формування асертивної поведінки як професійно важливої якості особистості студентів вищої школи. Педагогічні інновації у фаховій освіті: зб. наук. пр. Ужгород: ЗакДУ, 2011. Вип. 2. С. 117-123.

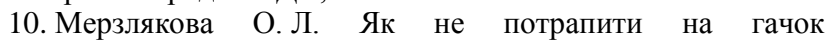
маніпулятора: програма занять для молоді. Київ: Шкільний світ, 2010. 128 с.

11. Мойсеєнко В. В. Психологічні особливості формування асертивної поведінки у студентів ВНЗ. Інсайт: зб. наук. праць студентів, аспірантів та молодих вчених. Херсон: ПП Вишемирський, 2017. Вип.14. С. 154-157.

12. Ражина Н. Ю. Формирование коммуникативной компетентности у студентов, обучающихся по специальности «Социально-культурный сервис и туризм», на основе ассертивной модели поведения: дис.... канд. пед. наук: 13.00.08. Омск, 2006. 146 с.

13. Самыгин С. И., Столяренко Л. Д. Психология управления. Ростов на Дону: Изд-во «Феникс», 1997. 512 c.

14. Семиченко В. А. Проблема особистісного розвитку й саморозвитку в контексті неперервної професійної освіти. Педагогіка і психологія. 2010. № 2 (67). С. 46-57.

15. Степанов С. С. Законы психологии. Советы психологаконсультанта. Санкт-Петербург: Питер, 2000. 154 с.

16. Хамська Н. Б. Виховання моральних основ культури поведінки підлітків у позаурочній діяльності: дис. ... канд. пед. наук: 13.00.017. Київ, 1997. 221 с.

17. Хохлова Е.В. Конструктивная агрессивность в 
формировании навыков ассертивного поведения студентов вуза: дис.... канд. психол. наук: 19.00.07. Нижний Новгород, 2008. 220 с.

18. Шамиева В. А. Ассертивность в структуре личности субъекта адаптации: автореф. дисс. ... канд. психол. наук: 19.00.01. Хабаровск, 2009. 23 с.
19. Ramirez J. Relationship of counselor assertiveness and therapeutic effectiveness in treating depression: diss. in psychology submitted for the PhD Degree. Texas Tech University, 1978. 107 p. URL: http://esr.lib.ttu.edu/bitstream/handle/2346/9359/3129500117 2591.pdf?sequence=1 (дата звернення: 18.03.2018).

\section{REFERENCES}

1. Bishop, S. (2001). Trening assertivnosti [Assertiveness training]. Sankt-Peterburg: Piter [in Russian].

2. Buyanova, M.V. (2004). Lichnostnye i situativnye faktory motivatsii dostizheniya [Personal and situational factors of achievement motivation]. In Ananevskie chteniya-2004. Materialy nauchno-prakticheskoy konferentsii [Ananyev Readings-2004. Materials of the scientific and practical conference]. Sankt-Peterburg: Izdatelstvo Sankt-Peterburgskogo universiteta (pp. 243-244) [in Russian].

3. Hluboka, I.O. (2016). Osoblyvosti stvorennia psykholohichnykh umov rozvytku asertyvnoi povedinky uchniv profesiinotekhnichnykh navchalnykh zakladiv [Peculiarities of creating of psychological conditions for the development of assertive behavior of vocational schools students]. Molodyi vchenyi [Young scientist], 5, 548-552 [in Ukrainian].

4. Grimak, L.P. (1991). Obschenie s soboy. Nachala psihologii aktivnosti [Communication with yourself. The beginnings of the psychology of activity]. Moskva: Izdatelstvo politicheskoy literatury [in Russian].

5. Kozych, I.V. (2014). Asertyvna povedinka yak novoutvorennia protsesu formuvannia konfliktolohichnoi kompetentnosti maibutnoho pedahoha vyshchoi shkoly [Assertive behavior as a new formation of the process of formation of conflict competence of the future lecturer of higher education institution]. Visnyk Zaporizkoho natsionalnoho universytetu. Pedahohichni nauky [Bulletin of Zaporizhia National University. Pedagogical sciences], 1, 135-143 [in Ukrainian].

6. Korobkova, T.A. (2000). Assertivnost kak vid pedagogicheskoy kommunikatsii [Assertiveness as a type of pedagogical communication]. In Sbornik nauchnyh trudov konferentsii "Vysokie tehnologii $\mathrm{v}$ pedagogicheskom protsesse" [Collection of scientific papers of the conference "High technologies in the pedagogical process"]. Nizhniy Novgorod: Izdatelstvo VIPI (pp. 138-139) [in Russian].

7. Marchuk, L.M. (2013). Asertyvna pozytsiia studenta yak zmistovna kharakterystyka ekzystentsii [Assertive position of the student as a meaningful characteristic of existence]. In Aktualni problemy psykholohii: zbirnyk naukovykh prats Instytutu psykholohii imeni H.S. Kostiuka T. XI: Sotsialna psykholohiia [Actual problems of psychology: collection of scientific works of H.S. Kostiuk Institute of Psychology. Vol. XI: Social psychology]. Kyiv: DP «Informatsiino-analitychne ahentstvo», Issue 6 (pp. 95-102) [in Ukrainian].

8. Marchuk, L.M., Sobol, N.M. (n.d.). Psykholoho-pedahohichni aspekty formuvannia asertyvnoi povedinky studentiv vyshchoi shkoly [Psychological and pedagogical aspects of the formation of assertive behavior of higher education institutions students].

URL: http://elar.khnu.km.ua/jspui/bitstream/123456789/3669/1/6.p df [in Ukrainian].

9. Marchuk, L.M. (2011). Formuvannia asertyvnoi povedinky yak profesiino vazhlyvoi yakosti osobystosti studentiv vyshchoi shkoly [Formation of assertive behavior as a professionally important quality of personality of higher education institutions students]. Pedahohichni innovatsii u fakhovii osviti: zbirnyk naukovykh prats [Pedagogical innovations in professional education: collection of scientific works]. Uzhhorod: ZakDU, 2, 117-123 [in Ukrainian].

10. Merzliakova, O.L. (2010). Yak ne potrapyty na hachok manipuliatora: prohrama zaniat dlia molodi [How not to fall for the hook manipulator: a program for young people]. Kyiv: Shkilnyi svit [in Ukrainian].

11. Moiseienko, V.V. (2017). Psykholohichni osoblyvosti formuvannia asertyvnoi povedinky u studentiv VNZ [Psychological peculiarities of the formation of assertive behavior of higher education institution students]. Insait: zbirnyk naukovykh prats studentiv, aspirantiv ta molodykh vchenykh [Insight: Collection of scientific works of students, postgraduate students and young scientists], 14, 154-157 [in Ukrainian].

12. Razhina, N.Y. (2006). Formirovanie kommunikativnoy kompetentnosti u studentov, obuchayuschihsya po spetsialnosti "Sotsialno-kulturnyy servis i turizm", na osnove assertivnoy modeli povedeniya [Formation of communicative competence among students studying in the specialty "Sociocultural service and tourism", based on an assertive model of behavior] (PhD diss.). Omsk [in Russian].

13. Samygin, S.I., Stolyarenko, L.D. (1997). Psihologiya upravleniya [Psychology of management]. Rostov na Donu: Izd-vo «Feniks» [in Russian].

14. Semychenko, V.A. (2010). Problema osobystisnoho rozvytku y samorozvytku $\mathrm{v}$ konteksti neperervnoi profesiinoi osvity [The problem of personal development and self-development in the context of continuing professional education]. Pedahohika i psykholohiia [Pedagogy and psychology], 2 (67), 4657 [in Ukrainian].

15. Stepanov, S.S. (2000). Zakony psihologii. Sovety psihologakonsultanta [Laws of psychology. Advice from a counseling psychologist]. Sankt-Peterburg: Piter [in Russian].

16. Khamska, N.B. (1997). Vykhovannia moralnykh osnov kultury povedinky pidlitkiv u pozaurochnii diialnosti [Upbringing of moral foundations of behavior culture of teenagers in extracurricular activities] (PhD diss.). Kyiv [in Ukrainian].

17. Hohlova, E.V. (2008). Konstruktivnaya agressivnost v formirovanii navykov assertivnogo povedeniya studentov vuza [Constructive aggressiveness in the formation of assertive behavior skills of higher education institution students] (PhD diss.). Nizhniy Novgorod [in Russian].

18. Shamieva, V.A. (2009). Assertivnost v strukture lichnosti subekta adaptatsii [Assertiveness in the structure of the personality of the subject of adaptation] (Extended abstract of $\mathrm{PhD}$ dissertation). Habarovsk [in Russian]. 